\title{
The effect of mixed agricultural feedstocks on steam pretreatment, enzymatic hydrolysis, and cofermentation in the lignocellulose-to-ethanol process
}

\author{
Fredrik Nielsen $^{1}$ - Mats Galbe ${ }^{1}$ - Guido Zacchi ${ }^{1}$ • Ola Wallberg ${ }^{1}$ \\ Received: 15 January 2019 / Revised: 27 May 2019 / Accepted: 28 May 2019 / Published online: 13 June 2019 \\ (C) The Author(s) 2019
}

\begin{abstract}
Second-generation fuel ethanol is typically researched using one type of raw material as feedstock. However, the variability in the supply and quality of biomass calls for an expansion of the feedstock base to ensure sufficient supply for commercial-scale production. By expanding the feedstock base and using mixtures in the conversion process, the biomass supply can be improved and associated economic risks can be hedged. However, the heterogeneity of feedstock mixtures requires conversion processes that can accommodate mixtures with no or minimal reduction in conversion efficiency compared to processing single feedstocks. In this study, the effects of using mixtures of wheat straw and corn stover on conversion efficiency and ethanol yield were investigated. The feedstocks and mixtures thereof were pretreated with dilute acid-catalysed steam pretreatment, and saccharified and cofermented using different simultaneous saccharification and cofermentation (SSCF) configurations, employing commercial cellulolytic enzymes and a xylose-fermenting strain of Saccharomyces cerevisiae. Process ethanol yields, based on total glucose and xylose in the raw material, were maximised by SSCF configurations that emphasise the saccharification efficiency over cofermentation efficiency. Ethanol concentrations exceeding $50 \mathrm{~g} \mathrm{~L}^{-1}$ and process ethanol yields of 74-78\% of the theoretical maximum were achieved across the range of feedstocks and feedstock mixtures studied. The narrow range of the ethanol yields suggests that wheat straw and corn stover can be used interchangeably and mixed in the proposed lignocelluloseto-ethanol process without significant negative effects on conversion efficiency and process economics.
\end{abstract}

Keywords Mixed feedstocks $\cdot$ SSCF $\cdot$ Cofermentation $\cdot$ Prefermentation $\cdot$ Prehydrolysis $\cdot$ Xylose fermentation $\cdot$ Saccharomyces cerevisiae $\cdot$ Lignocellulose

\section{Introduction}

Large amounts of lignocellulosic feedstocks derived from agricultural residues are required to produce second-generation

Fredrik Nielsen

fredrik.nielsen.bjorck@gmail.com

Ola Wallberg

ola.wallberg@chemeng.lth.se

Mats Galbe

mats.galbe@chemeng.lth.se

Guido Zacchi

guido.zacchi@chemeng.lth.se

1 Department of Chemical Engineering, Lund University, P.O. Box 124, SE-221 00 Lund, Sweden bioethanol on a commercial scale. The required amount has been estimated to be $\sim 2000$ metric tonnes per day to maximise the benefits of economy of scale [1,2]. Feedstocks typically need to be sourced in proximity of the plant to minimise the cost of transportation [2]. Moreover, a consistent yearround supply of a single kind of feedstock, with predictable composition and quality, and at an affordable cost, is desirable. However, the supply and quality of agricultural feedstocks vary over seasons and years, as well as geographical regions [1, 3-5], as does the price of the feedstock. Relying on a single feedstock can create supply barriers and incur prohibitive costs for the raw material. A broader feedstock base would help ensure an adequate supply to realise economies of scale [2], hedge supply risks [6,7], and minimise seasonal constraints and storage requirements $[6,7]$. Furthermore, a broad feedstock base can be used to minimise the cost of raw materials and hedge the sensitivity to price volatility [7]. A broad feedstock base can thereby contribute to de-risking of 
the supply chain for commercial-scale plants and reduce the main source of operational costs: the cost of raw materials [1].

There are additional advantages to be gained from mixing feedstocks and processing them together, rather than separately in successive campaigns. Mixing based on feedstock availability can reduce sourcing radius, and need for transportation and storage. Mixtures can also be formulated so as to reduce the variation in composition [8], gain synergies [9], and target specific physiochemical properties that are beneficial in the conversion process [8]. Improved uniformity of the feedstock composition over time reduces technological risk. In spite of these benefits, research on the conversion of lignocellulosic feedstocks to ethanol has largely been based on using a single feedstock, and little attention has been devoted to the efficiency of converting feedstock mixtures in the lignocellulose-toethanol process.

To improve the competitiveness of cellulosic ethanol, the substrate utilisation and conversion efficiency-and thereby the ethanol yield - must be maximised $[1,10]$. This implies that all sugars that can be taken up and metabolised by the microorganism must be liberated and converted to ethanol with minimal losses and by-product formation (Fig. 1). The main obstacle with mixtures in the biochemical conversion process is the inherent increase in structural and compositional heterogeneity of a mixture, originating from mixing different anatomical parts of the same crop $[12,13]$ or different crops (as discussed herein) [9, 14-17]. Not all pretreatment methods can be used to treat all types of feedstocks and remove the recalcitrant barriers to deconstruction [18]. The performance of most pretreatment methods will differ when applied to different feedstocks. This limits the alternatives for treating feedstock mixtures. The commercially pursued pretreatment methods, auto-catalysed and dilute acid-catalysed steam pretreatment [19], can be applied to a broad range of feedstocks [18], but the optimal pretreatment conditions differ depending on the feedstock [20]. A trade-off must be made in dilute acidcatalysed steam pretreatment between improved susceptibility of the lignocellulose to enzymatic digestion on the one hand, and the loss of fermentable sugars and the formation of inhibitors on the other (Fig. 1) [20]. The complexity of this trade-off may be exacerbated by the heterogeneity of feedstock mixtures. Thus, using feedstock mixtures can lead to suboptimal pretreatment, resulting in lower total sugar yields and reduced ethanol yields after enzymatic hydrolysis and cofermentation, compared to single feedstocks. However, feedstocks with similar properties can probably be mixed and subsequently pretreated with dilute acid-catalysed steam pretreatment, to realise the benefits of feedstock mixing. Agricultural residues, such as straw from herbaceous crops, have similar cell wall structures and chemical compositions [21], and similar optimal pretreatment conditions in dilute acid-catalysed steam pretreatment [22-25]. This makes them suitable candidates for feedstock mixing.

The pretreatment conditions that maximise individual sugar recoveries and yields in pretreatment are often not the same as those that maximise total sugar yields for the whole process, nor the conditions that promote the most efficient cofermentation of the sugars to ethanol. Simultaneous saccharification and cofermentation (SSCF) has been proposed as a feasible approach to attain high ethanol yields from pretreated lignocellulosic biomass, reviewed in [26]. It combines enzymatic hydrolysis with cofermentation of glucose and xylose in an integrated step under conditions that typically represent a compromise between enzymatic hydrolysis and fermentation optima [26]. The temperature is the most notable compromise, which typically is above optima for commonly used Saccharomyces cerevisiae $[27,28]$ and below that of the most common cellulase systems [29]. The suboptimal temperatures can constrain enzymatic hydrolysis rates [26] and negatively affect yeast viability and fermentation efficiency in lignocellulosic hydrolysates [27, 28, 30-33]. However, SSCF has important benefits. It can reduce inhibition of cellulolytic enzyme systems by fermentation $[26,34]$ and improve xylose consumption and metabolism in cofermentation by controlled release of sugars [35-37]. Thus, the preferential consumption of glucose by xylose-utilising $S$. cerevisiae [38, 39] can be circumvented, and xylose uptake [35] and overall ethanol yields can be improved [37]. Various modifications
Fig. 1 Lignocellulose-to-ethanol process. Schematics illustrating the lignocellulose-to-ethanol process and the yield losses that need to be balanced in global optimisation of the processing chain (adapted from [11])

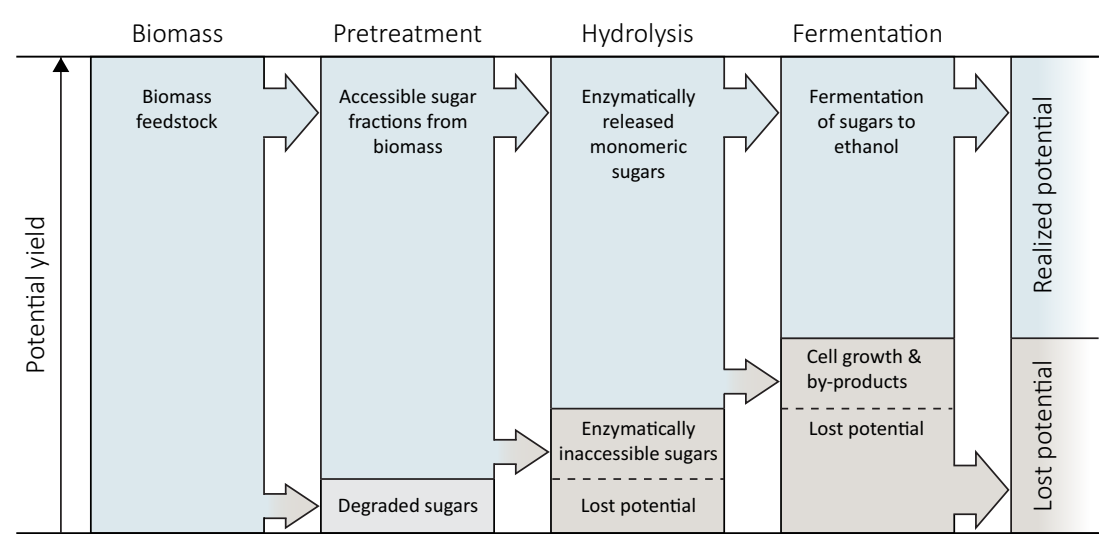


have been proposed to tailor SSCF to the characteristics of the fermenting microorganism, the cellulolytic enzyme system, and the pretreated feedstock, thereby improving the efficiency of cofermentation of glucose and xylose [40-42] and enzymatic hydrolysis in the integrated cofermentation design [43, 44].

The processing steps in the lignocellulose-to-ethanol process are highly interconnected (Fig. 1); a change in one process parameter affects the entire process downstream of that point. The whole chain of unit operations - pretreatment, saccharification, and cofermentation - must therefore be evaluated and globally optimised to maximise the ethanol yield and concentration. In spite of this, many studies fail to perform integrative process analyses and focus instead on optimisation of either the pretreatment or bioconversion steps [45].

In this study, we examined the effect of various ratios of wheat straw and corn stover in feedstock mixtures on the efficiency of steam pretreatment, enzymatic hydrolysis, and cofermentation of glucose and xylose in the integrated process, and on the final ethanol yields and concentrations. Corn stover and wheat straw are two of the most abundant agricultural residues in Europe and North America. They are attractive raw materials for bioconversion because of the relatively low lignin content, compared to other herbaceous crops and woody biomass, and their susceptibility to alkali and acidcatalysed hydrolysis [21]. Single feedstocks and feedstock mixtures were steam pretreated and subsequently saccharified and converted to ethanol using different SSCF configurations, emphasising either cofermentation efficiency [40] or enzymatic hydrolysis efficiency [43, 44]. The aim was to achieve industrially relevant ethanol yields and concentrations using commercial enzymes and a xylose-fermenting strain of Saccharomyces cerevisiae, with a goal of achieving ethanol concentrations exceeding $50 \mathrm{~g} \mathrm{~L}^{-1}$ and ethanol yields above $80 \%$ of the theoretical maximum, based on the glucose and xylose available in the feedstocks.

\section{Materials and methods}

\subsection{Raw materials and pretreatment}

Wheat straw (Johan Håkansson Lantbruksprodukter), corn stover (provided by State Grid Corporation of China, Handan City, Hebei Province, China), and mixtures of the two at ratios of $3: 1,1: 1$, and 1:3, based on dry matter (DM), were treated by dilute acid-catalysed steam pretreatment. The feedstocks and feedstock mixtures were denoted WS100 to WS0, based on the percentage of wheat straw DM in the mixture. The feedstock ratios in the mixtures were chosen to study the effects of mixtures by increasing amounts of either feedstock in a process flow of the other. The compositions of the raw materials are listed in Table 1. The pretreatment conditions used for the separate feedstocks and feedstock mixtures were based on reported optima $[22,25]$. The feedstock was soaked for $20 \mathrm{~min}$ in $0.2 \mathrm{wt} \%$ aqueous $\mathrm{H}_{2} \mathrm{SO}_{4}$ at room temperature. The liquid/solid ratio was $20 \mathrm{~kg} \mathrm{~kg}^{-1}$ of DM. The soaked feedstock was dewatered by filtration with a filter press (HP5M, Fischer Maschinenfabrik $\mathrm{GmbH}$ ), yielding a DM content of $52 \pm 2 \mathrm{wt} \%$. The dewatered feedstock was steam pretreated in batches of $500 \mathrm{~g} \mathrm{DM}$ at $190{ }^{\circ} \mathrm{C}$ for $5 \mathrm{~min}$ in a preheated $10-\mathrm{L}$ batch pretreatment reactor. The pretreatment reactor has been described previously [46]. The pretreated material from 5 consecutive batches was pooled and collected.

\subsection{Microorganism}

Fermentation was performed with the non-commercial xylose-fermenting strain Saccharomyces cerevisiae KE6-12 (Taurus Energy AB), which overexpresses an endogenous xylulokinase and harbours genes from Scheffersomyces stipitis that encode for xylose reductase and xylitol dehydrogenase. The strain was developed by evolutionary engineering $[47,48]$ of the industrial strain $S$. cerevisiae TMB3400 [49] to improve inhibitor tolerance and xylose-fermenting capacity. The stock culture containing $20 \mathrm{wt} \%$ glycerol in water was stored at $-80{ }^{\circ} \mathrm{C}$.

\subsection{Cultivation of yeast}

Precultures were cultivated in $250-\mathrm{mL}$ shake flasks with a 150 -mL sterile minimal medium, containing $20 \mathrm{~g} \mathrm{~L}^{-1}$ glucose, $20 \mathrm{~g} \mathrm{~L}^{-1}$ xylose, $7.5 \mathrm{~g} \mathrm{~L}^{-1}\left(\mathrm{NH}_{4}\right)_{2} \mathrm{SO}_{4}, 3.75 \mathrm{~g} \mathrm{~L}^{-1} \mathrm{KH}_{2} \mathrm{PO}_{4}$, and $0.75 \mathrm{~g} \mathrm{~L}^{-1} \mathrm{MgSO}_{4}$, supplemented with $1 \mathrm{~mL} \mathrm{~L}^{-1}$ vitamin solution and $10 \mathrm{~mL} \mathrm{~L}^{-1}$ trace element solution, as described previously [50]. The $\mathrm{pH}$ of the medium was adjusted to 5.5 with $5 \mathrm{M} \mathrm{NaOH}$. The precultures were inoculated with $300 \mu \mathrm{L}$ of the stock cell solution and incubated at $30^{\circ} \mathrm{C}$ in an orbital shaker (Lab-Therm, Kühner) at $180 \mathrm{rpm}$ for $24 \mathrm{~h}$.

The yeast was propagated sequentially by aerobic batch cultivation on molasses (Nordic Sugar A/S) and aerobic fedbatch cultivation on molasses and hydrolysate liquor from the pretreated WS50 feedstock mixture. Cultivation was performed in sterilised 2-L Labfors bioreactors (Infors AG) equipped with two six-blade Rushton turbines. The reactor diameter/impeller diameter ratio was 3 , and the reactor height/diameter ratio was 1.7. Carbon dioxide and oxygen in the bioreactor gas effluent were monitored by in situ gas sensors (BCP-CO2 and BCP-O2, BlueSens gas sensors $\mathrm{GmbH}$ ). Batch cultivation was performed with $50 \mathrm{~g} \mathrm{~L}^{-1}$ molasses solution supplemented with $23.5 \mathrm{~g} \mathrm{~L}^{-1}\left(\mathrm{NH}_{4}\right)_{2} \mathrm{SO}_{4}, 3 \mathrm{~g} \mathrm{~L}^{-1}$ $\mathrm{KH}_{2} \mathrm{PO}_{4}, 2.25 \mathrm{~g} \mathrm{~L}^{-1} \mathrm{MgSO}_{4} \cdot 7 \mathrm{H}_{2} \mathrm{O}, 33 \mu \mathrm{g} \mathrm{L}^{-1}$ biotin, and $120 \mu \mathrm{L} \mathrm{L}^{-1}$ VitaHop (BetaTec). The molasses contained $40 \mathrm{wt} \%$ fermentable sugars. Cell propagation was initiated by inoculation with the preculture. Batch cultivation was 
Table 1 Composition of raw materials. Composition of structural carbohydrates in wheat straw and corn stover expressed as wt $\%$ of DM, where $\overline{\boldsymbol{x}}$ is the arithmetic mean and $s$ the standard deviation

\begin{tabular}{|c|c|c|c|c|}
\hline & \multicolumn{2}{|c|}{ Wheat straw } & \multicolumn{2}{|c|}{ Corn stover } \\
\hline & $\bar{x}$ & $s$ & $\bar{x}$ & $s$ \\
\hline Glucan & 36.9 & 0.3 & 37.5 & 0.7 \\
\hline Xylan & 23.6 & 0.2 & 22.7 & 0.3 \\
\hline Galactan & 2.6 & 0.2 & 2.8 & 0.1 \\
\hline Arabinan & 3.4 & 0.1 & 3.5 & 0.1 \\
\hline Mannan & 1.0 & 0.1 & 0.8 & 0.3 \\
\hline Lignin & 20.8 & 0.2 & 21.9 & 0.5 \\
\hline Ash & 4.3 & 0.4 & 2.8 & $<0.1$ \\
\hline Total determined: & 92.6 & & 91.9 & \\
\hline
\end{tabular}

performed with a working volume of $0.5 \mathrm{~L}$, a constant aeration rate of $1 \mathrm{vvm}$, and an agitation rate of $700 \mathrm{rpm}$. The $\mathrm{pH}$ was maintained automatically at 5.2 with $2.5 \mathrm{M} \mathrm{NaOH}$. The batch phase was concluded when all the sugars had been consumed, as indicated by the evolution of carbon dioxide and oxygen in the bioreactor gas effluent.

The feed solution for the fed-batch phase consisted of diluted hydrolysate liquor from pretreatment of WS50, supplemented with $150 \mathrm{~g} \mathrm{~L}^{-1}$ molasses. The hydrolysate liquor in the feed solution led to inhibitor concentrations in the final working volume that corresponded to the concentrations in a broth of pretreated WS50 with a 7.5-wt\% water-insoluble solid (WIS) load. The purpose of the hydrolysate liquor in the fed-batch phase was to short-term adapt the yeast to the environmental conditions in the fermentation experiments, as previously described [51]. The feed solution was pulse-fed to the bioreactor at a constant rate for $20 \mathrm{~h}$, reaching a final working volume of $1.5 \mathrm{~L}$. The reactor was aerated by sparging at a constant rate of $1 \mathrm{vvm}$, based on the final volume, and the $\mathrm{pH}$ was maintained at 5.2, as described above. The propagated yeast cells were harvested by centrifugation $(3800 \times \mathrm{g}, 10 \mathrm{~min})$ and washed with $9 \mathrm{~g} \mathrm{~L}^{-1}$ sterile $\mathrm{NaCl}$ solution.

\subsection{Enzymatic hydrolysis}

Enzymatic hydrolysis was performed in sterilised 2-L Labfors bioreactors equipped with an anchor impeller and a pitched six-blade turbine. The reactor diameter/ impeller diameter ratio was 1.5 for the anchor impeller and 1.7 for the pitched six-blade turbine, and the reactor height/diameter ratio was 1.7. Enzymatic hydrolysis was performed with a working mass of $1 \mathrm{~kg}$ of pretreated feedstock. The hydrolysate liquor was separated from the solid fraction by filtration, and the $\mathrm{pH}$ subsequently adjusted to 5.5 with $12.5 \mathrm{M} \mathrm{NaOH}$. Cellic CTec3 enzyme preparation (Novozymes A/S) was then dispersed in the hydrolysate liquor, which was subsequently added back to the solid fraction. This procedure promoted even enzyme dispersion in the bioreactor prior to liquefaction. Hydrolysis was performed at $45{ }^{\circ} \mathrm{C}$ for $96 \mathrm{~h}$ with an enzyme load of 10 filter paper units (FPU) $\mathrm{g}^{-1}$ WIS. The temperature was controlled based on the heating jacket temperature during the first $12 \mathrm{~h}$, after which it was controlled based on the broth temperature. Total WIS loads close to those of the original slurries (Table 2), in the range of 12.9-15.0 wt\%, were obtained after the addition of enzymes and neutralising agent. The $\mathrm{pH}$ was maintained at 5 by manual addition of $5 \mathrm{M} \mathrm{NaOH}$.

\subsection{Simultaneous saccharification and cofermentation}

SSCF was performed using two different configurations: fed-batch SSCF with prefermentation and batch SSCF with prehydrolysis (Fig. 2), henceforth referred to as fed-batch SSCF and hybrid SSCF, respectively. SSCF was performed in a sterilised 2-L Labfors bioreactor equipped with an anchor impeller and a pitched 6-blade turbine, as described above, using $1 \mathrm{~kg}$ of pretreated feedstock. The $\mathrm{pH}$ of the slurry was adjusted to 5.5 with $12.5 \mathrm{M} \mathrm{NaOH}$ prior to fermentation, and was supplemented with $0.5 \mathrm{~g} \mathrm{~L}^{-1}\left(\mathrm{NH}_{4}\right)_{2} \mathrm{HPO}_{4}, 0.125 \mathrm{~mL} \mathrm{~L}^{-1}$ VitaHop (BetaTec), and $0.4 \mathrm{~mL} \mathrm{~L}^{-1}$ Antifoam RD Emulsion (Dow Corning), based on the final volume. The fermentation broth was inoculated with a yeast load of $4 \mathrm{~g} \mathrm{~L}^{-1}$ dry matter, based on the final volume, and an overall enzyme load of Cellic CTec3 of 10 FPU $\mathrm{g}^{-1}$ WIS, based on total incoming WIS. Total WIS loads close to those of the original slurries (Table 2), in the range of $12.7-$ $14.7 \mathrm{wt} \%$, were obtained after addition of the enzymes, yeast, and supplements. The $\mathrm{pH}$ in the fermentation broth was maintained at 5.2 by automatic addition of $2.5 \mathrm{M}$ $\mathrm{NaOH}$ during fermentation. Agitation was maintained at $300 \mathrm{rpm}$ throughout fermentation. 
Table 2 Composition of pretreated materials and hydrolysate liquors. Composition of the WIS fractions and content of select sugars and inhibitors in the hydrolysate liquor from steam-pretreated feedstock mixtures, where $\overline{\boldsymbol{x}}$ is the arithmetic mean and $s$ the standard deviation

\begin{tabular}{|c|c|c|c|c|c|c|c|c|c|c|}
\hline & \multicolumn{10}{|c|}{ Feedstock mixture } \\
\hline & \multicolumn{2}{|c|}{ WS100 } & \multicolumn{2}{|c|}{ WS75 } & \multicolumn{2}{|c|}{ WS50 } & \multicolumn{2}{|c|}{ WS25 } & \multicolumn{2}{|l|}{ WS0 } \\
\hline & $\bar{x}$ & $s$ & $\bar{x}$ & $s$ & $\bar{x}$ & $s$ & $\bar{x}$ & $s$ & $\bar{x}$ & $s$ \\
\hline WIS content (wt $\%$ ) & 14.6 & 0.1 & 14.3 & 0.2 & 13.1 & 0.2 & 15.2 & $<0.1$ & 14.4 & 0.1 \\
\hline Liquid volume (L) & 8.2 & & 8.9 & & 10.2 & & 8.9 & & 9.0 . & \\
\hline \multicolumn{11}{|c|}{ WIS (\% of dry weight) } \\
\hline Glucan & 54.8 & 0.9 & 50.5 & 1.7 & 51.1 & 1.4 & 49.2 & 1.1 & 49.7 & 0.6 \\
\hline Xylan & 2.6 & $<0.1$ & 3.3 & 0.1 & 3.9 & 0.2 & 4.3 & 0.1 & 5.3 & $<0.1$ \\
\hline Galactan & 0.2 & $<0.1$ & 0.1 & $<0.1$ & 0.2 & $<0.1$ & 0.0 & $<0.1$ & 0.2 & $<0.1$ \\
\hline Arabinan & 0.1 & $<0.1$ & 0.0 & $<0.1$ & 0.1 & $<0.1$ & 0.0 & $<0.1$ & 0.2 & $<0.1$ \\
\hline Mannan & 0.5 & $<0.1$ & 0.6 & $<0.1$ & 0.5 & $<0.1$ & 0.5 & $<0.1$ & 0.6 & $<0.1$ \\
\hline Lignin & 27.6 & 0.3 & 30.1 & 0.1 & 28.4 & 0.1 & 29.4 & 0.3 & 30.3 & 0.6 \\
\hline Ash & 6.7 & $<0.1$ & 6.4 & 0.7 & 6.6 & $<0.1$ & 6.8 & 0.2 & 5.0 & 0.1 \\
\hline Total determined & 92.5 & & 91.0 & & 90.8 & & 90.2 & & 91.3 & \\
\hline \multicolumn{11}{|c|}{ Hydrolysate liquor $\left(\mathrm{g} \mathrm{L}^{-1}\right)$} \\
\hline Glucose $^{\mathrm{a}}$ & 11.1 & 0.3 & 9.4 & $<0.1$ & 5.9 & 0.1 & 8.0 & 0.1 & 5.0 & 0.3 \\
\hline Xylose $^{a}$ & 54.3 & 0.6 & 41.7 & 0.2 & 37.6 & 0.8 & 39.5 & 0.1 & 36.4 & 0.5 \\
\hline Galactose $^{\mathrm{a}}$ & 3.1 & 0.1 & 2.9 & $<0.1$ & 2.6 & $<0.1$ & 3.4 & $<0.1$ & 3.1 & 0.2 \\
\hline Arabinose $^{\mathrm{a}}$ & 5.6 & 0.2 & 5.0 & $<0.1$ & 4.0 & 0.1 & 4.7 & $<0.1$ & 4.0 & 0.2 \\
\hline Mannose $^{a}$ & 4.2 & 0.1 & 3.6 & 0.1 & 2.9 & 0.1 & 3.6 & 0.1 & 2.9 & 0.2 \\
\hline Acetic acid & 3.5 & & 2.7 & & 2.0 & & 2.1 & & 1.8 & \\
\hline HMF & 0.2 & & 0.3 & & 0.2 & & 0.3 & & 0.3 & \\
\hline Furfural & 2.2 & & 2.4 & & 1.7 & & 2.0 & & 1.8 & \\
\hline
\end{tabular}

${ }^{\mathrm{a}}$ Including both monomeric and oligomeric forms

Fig. 2 Schematics of the different SSCF configurations. Schematics illustrating the two SSCF configurations: a fed-batch SSCF with prefermentation of the hydrolysate liquor (fed-batch SSCF) and $\mathbf{b}$ batch SSCF with prehydrolysis (hybrid SSCF) a.

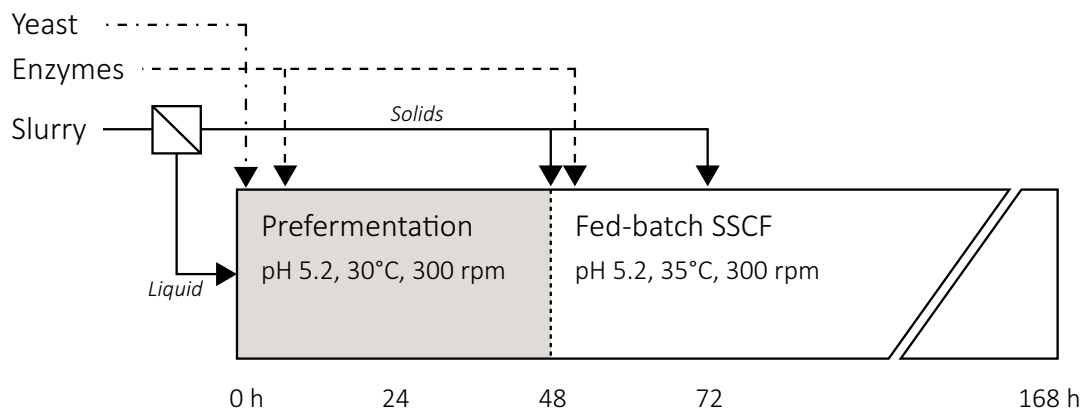

b.

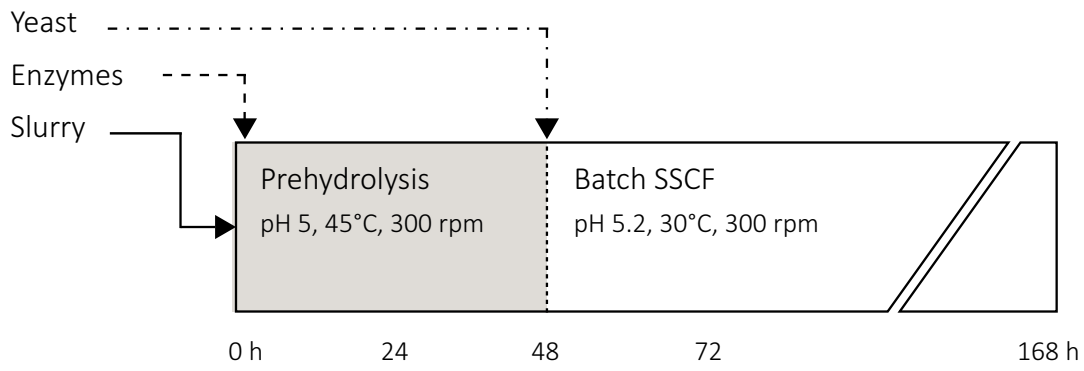




\subsubsection{Fed-batch SSCF with prefermentation}

The two-step fed-batch SSCF configuration consisted of prefermentation of the hydrolysate liquor followed by fedbatch SSCF, as previously described [40], and is outlined in Fig. 2a. The pretreatment hydrolysate liquor was separated from the solids by filtration using an HP5M filter press. The retained filter cake had a WIS content of $43 \pm 2 \mathrm{wt} \%$. Fermentation was performed sequentially by batch prefermentation of the separated hydrolysate liquor, followed by fed-batch SSCF of the unwashed solids. The hydrolysate liquor, supplements, and yeast were added at the outset, and prefermented at $30{ }^{\circ} \mathrm{C}$ for $48 \mathrm{~h}$. The temperature was controlled based on the broth temperature throughout the fermentation. An enzyme load of $2 \mathrm{FPU} \mathrm{g}^{-1}$ WIS, based on the total incoming WIS, was added after $4 \mathrm{~h}$ to hydrolyse the oligosaccharides in the hydrolysate liquor. After prefermentation for $48 \mathrm{~h}$, half of the solids were added to the prefermented hydrolysate liquor together with the remaining enzymes, yielding a total cellulolytic activity of $10 \mathrm{FPU} \mathrm{g}^{-1}$ WIS, based on total incoming WIS. The temperature was increased to $35^{\circ} \mathrm{C}$ to enhance enzyme activity. Remaining solids were added after $72 \mathrm{~h}$, and SSCF was terminated after $168 \mathrm{~h}$.

\subsubsection{Hybrid SSCF with prehydrolysis}

The hybrid SSCF configuration consisted of prehydrolysis of the whole slurry followed by batch SSCF, and is outlined in Fig. 2b. It was a modified version of that described by Öhgren et al. [43]. Pretreated feedstock, supplements, and the full enzyme load were added at the outset and prehydrolysis was performed at $45^{\circ} \mathrm{C}$ for $48 \mathrm{~h}$. The temperature was controlled based on the heating jacket temperature during the first $12 \mathrm{~h}$, after which it was controlled based on the broth temperature. After $48 \mathrm{~h}$, the temperature was decreased to $30^{\circ} \mathrm{C}$ and the bioreactor was inoculated with the harvested yeast. SSCF was terminated after $168 \mathrm{~h}$.

\subsection{Analytical procedures}

Dry matter content [28] and WIS [29] were measured in triplicates according to standard methods (National Renewable Energy Laboratory, NREL). Extracellular metabolites, inhibitors, and sugars were quantified by high-performance liquid chromatography (HPLC) on a Shimadzu HPLC system equipped with an RID-10A refractive index detector (Shimadzu). Samples for carbohydrate analysis were $\mathrm{pH}$ adjusted to 5 with $\mathrm{CaCO}_{3}$, filtered through 0.20 - $\mu \mathrm{m}$ syringe filters (GVS Filter Technology), and stored at $-20^{\circ} \mathrm{C}$ until analysis. Extracellular metabolites, organic acids, and degradation products in the samples were analysed using isocratic ion-exchange chromatography with an Aminex HPX-87H column (Bio-Rad Laboratories) at $50{ }^{\circ} \mathrm{C}$. The eluent was
$5 \mathrm{mM} \mathrm{H}_{2} \mathrm{SO}_{4}$ applied at a flow rate of $0.5 \mathrm{~mL} \mathrm{~min}^{-1}$. Sugars and xylitol in the samples were quantified with isocratic ionexchange chromatography on an Aminex HPX-87P column (Bio-Rad Laboratories) at $85^{\circ} \mathrm{C}$. Deionised water was used as

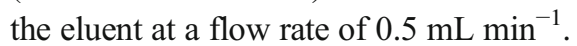

Soluble carbohydrates and pretreatment degradation products in the hydrolysate liquor were quantified by acid hydrolysis and HPLC [52]. The contents of structural carbohydrates, lignin, and ash in the water-insoluble fraction of the raw material, the pretreated material, and the residues after enzymatic hydrolysis and cofermentation were measured in triplicate using standard NREL methods [53]. The monomeric sugars from the assay were measured using high-performance anionexchange chromatography with pulsed amperometric detection on an ICS-3000 chromatography system (Dionex), using a CarboPac PA1 analytical column (Dionex). Deionised water was used as eluent at a flow rate of $1 \mathrm{~mL} \mathrm{~min}$.

\subsection{Yield definitions and calculations}

Standard assumptions for glucose and ethanol yield calculations are typically those of constant volume and liquid density throughout the reaction. However, these assumptions will result in increasing errors as solids loading increase in enzymatic hydrolysis and SSCF [54, 55]. To more accurately estimate the yields, the degree of hydrolysis in enzymatic hydrolysis and SSCF was calculated based on the change in measured composition of the WIS before and after hydrolysis, as described previously [44]. Although the degradation of polysaccharides in the cell wall of the yeast may affect glucan measurements in the SSCF residues [56], the bias with the current yeast pitch is small, and the applied method provides a measure of the difference in hydrolysability of the pretreated feedstocks.

Ethanol yields were calculated in three ways: metabolic, technical, and process ethanol yield. The metabolic ethanol yield was based on the glucose and xylose consumed during SSCF, and reflects cofermentation performance. The technical ethanol yield was based on the total amount of glucose and xylose supplied in SSCF (i.e. the sum of the glucose and xylose present in the slurries after pretreatment, including monomers, oligomers, and polymers), and reflects cofermentation and enzymatic hydrolysis performance. The process ethanol yield was based on total glucose and xylose in the raw material, and performance of the entire process chain. The ethanol yields were calculated based on compositional analyses, HPLC measurements, measured liquid densities, measured WIS content, and applied working weight, as described previously [44]. The percentage of the theoretical maximum ethanol yield was based on a theoretical stoichiometric yield of $0.51 \mathrm{~g} \mathrm{~g}^{-1}$ on glucose and xylose. 


\section{Results and discussion}

\subsection{Pretreatment of feedstock mixtures}

Dilute acid-catalysed steam pretreatment was performed to extract hemicellulose and redistribute lignin in the biomass, and make it more susceptible to enzymatic deconstruction. The pretreatment conditions were chosen to achieve ethanol yields and concentrations of commercial relevance after SSCF, preferably ethanol concentrations exceeding $50 \mathrm{~g} \mathrm{~L}^{-1}$ and ethanol yields exceeding $80 \%$ of the theoretical maximum ethanol yield from total glucose and xylose in the feedstock.

\subsubsection{Pretreatment conditions}

The optimal conditions for dilute acid-catalysed steam pretreatment of wheat straw in batch pretreatment units have been established to be $190-200{ }^{\circ} \mathrm{C}$ for $5-10$ min using feedstock presoaked in $0.2-1 \mathrm{wt} \%$ aqueous $\mathrm{H}_{2} \mathrm{SO}_{4}[22,23]$. Optimal pretreatment conditions for corn stover have been established to be $160-200{ }^{\circ} \mathrm{C}$ for $5-20 \mathrm{~min}$, using $0.5-3 \mathrm{wt} \%$ aqueous $\mathrm{H}_{2} \mathrm{SO}_{4}$ for presoaking of the feedstock $[24,25,57]$. The different optima combine various temperatures, residence times, and acid concentrations, to balance the severity of the pretreatment. The optimal conditions are a compromise between improving the accessibility of cellulose to enzymes and minimising carbohydrate losses [57]. The optimal conditions are partly dependent on the enzyme loading and the performance of the enzyme system used to evaluate pretreatment [11].

The pretreatment conditions applied in this study were based on reported pretreatment conditions for wheat straw that maximised the yield of glucose and xylose after enzymatic hydrolysis, namely treatment at $190{ }^{\circ} \mathrm{C}$ for $10 \mathrm{~min}$ with $0.2 \mathrm{wt} \% \mathrm{H}_{2} \mathrm{SO}_{4}$ as a catalyst [22]. These conditions are also within the range that has been reported to be suitable for corn stover [25]. The suitability of the pretreatment conditions was assessed by trial pretreatments with the WS50 mixture. However, these pretreatment conditions diluted the feedstock mixtures excessively (WIS content $<11 \mathrm{wt} \%$ ), due to condensation of live steam, and the desired ethanol concentrations could, therefore, not be reached. To reduce dilution during pretreatment and enable the targets for ethanol yields and concentrations to be met simultaneously, the pretreatment time was shortened to $5 \mathrm{~min}$, reducing the amount of direct steam injected, and thus the dilution. The use of higher catalyst concentrations $\left(0.5 \mathrm{wt} \%\right.$ aqueous $\left.\mathrm{H}_{2} \mathrm{SO}_{4}\right)$ in pretreatment to compensate for the shorter residence time was investigated. However, this resulted in negligible differences in sugar yield after enzymatic hydrolysis, compared to $0.2 \mathrm{wt} \%$ aqueous $\mathrm{H}_{2} \mathrm{SO}_{4}$ at the same temperature and duration. Because the use of lower amounts of acid catalyst is favourable from an economic perspective (reduced cost of catalyst and need for neutralising agents), $190{ }^{\circ} \mathrm{C}$ for 5 min with $0.2 \mathrm{wt} \% \mathrm{H}_{2} \mathrm{SO}_{4}$ was chosen as the pretreatment conditions.

\subsubsection{Pretreatment results}

The WIS content and the compositions of the WIS and the hydrolysate liquor after pretreatment are given in Table 2 . The WIS contents of the pretreated materials were in the range $13.1-15.2 \mathrm{wt} \%$, and the variation was mainly due to variations in the degree of dilution caused by condensation of live steam during pretreatment. The recoveries of glucose and xylose after pretreatment were in the range $94-96 \%$ and $86-92 \%$, respectively (Fig. 3). The highest total recovery of glucose and xylose (95\%) was obtained with wheat straw (WS100), whereas recovery in the feedstock mixtures WS25 to WS75 and corn stover (WS0) was $90-91 \%$. The differences in total recovery of glucose and xylose were mainly due to differences in the recovery of xylose. The incomplete recovery of glucose and xylose was due to mass losses of the pretreated biomass from the collection vessel, and secondary degradation of solubilised hemicellulosic sugars [58]. The majority of the glucan remained in the lignocellulosic solids, whereas most of the hemicellulose was solubilised. There was a trend towards increasing recovery of xylose bound in hemicellulose in the lignocellulosic solids with increasing ratio of corn stover in the feedstock mixture. This indicates that hemicellulose in the corn stover was less susceptible to the pretreatment used. Major contributors to the differential recalcitrance are the differences in distribution of lignin in the plant cell wall, lignin chemistry (e.g., acylation and monolignol ratios), and cross-linking between carbohydrates and lignin [21]. Another structurally important factor that contributes is acylation of hemicellulose, in particular acetylation. The higher degree of acetylation in wheat straw, as indicated by the increasing amount of acetic acid in the pretreatment hydrolysate with increasing amounts of wheat straw in the mixture, contributes to the acidity during pretreatment and thereby the differential solubilisation and degradation of hemicellulose (Table 2).

\subsubsection{Evaluation of hydrolysability}

Enzymatic hydrolysis was performed on the whole slurry of pretreated biomass to evaluate the effect of identical pretreatment conditions for the separate feedstocks and the feedstock mixtures, as well as to assess the feasibility of achieving the desired ethanol yields and concentrations in the fermentative conversion process. The results are summarised in Table 3 . The degrees of glucan and xylan conversion in enzymatic hydrolysis were in the range 86-94\% and 76-96\%, respectively. Glucan conversion exhibited a tendency of lower degree of conversion with higher ratios of corn stover in the mixture. The decreasing degree of conversion was correlated to increasing amounts of hemicellulose and lignin retained in 


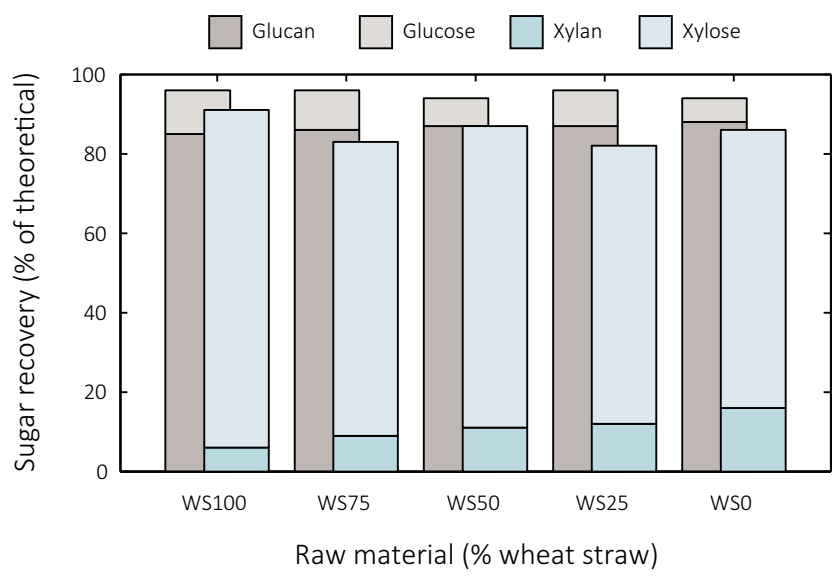

Fig. 3 Recovery of sugar and sugar polymers after pretreatment. Recovery of glucose and xylose in the WIS and hydrolysate liquor of dilute acid-catalysed steam-pretreated wheat straw, corn stover, and various mixtures of the two. Glucose and xylose were recovered as monomers and oligomers in the liquid phase and as glucan and xylan, respectively, in the solid phase

the solid fractions after pretreatment in feedstock mixtures with increasing ratios of corn stover (Table 2). These can shield the cellulose structures and make them less susceptible to enzymatic hydrolysis [18]. The degree of the xylan conversion was highly variable, which was of less importance as most of the xylan was hydrolysed and solubilised already during pretreatment (Fig. 3).

The total yield of glucose and xylose after pretreatment and enzymatic hydrolysis was in the range $82-89 \%$, based on the amounts of glucose and xylose in the incoming raw material (Fig. 4), and showed a decreasing yield with increasing ratios of corn stover in the feedstock mixtures. The overall glucose and xylose yields obtained for wheat

Table 3 Summary of the enzymatic hydrolysis performance and process feasibility. Summary of resulting conversion efficiencies, yields, and sugar concentrations for enzymatic hydrolysis assessment of process feasibility

Feedstock mixture

WS100 WS75 WS50 WS25 WS0

Degree of hydrolysis (\% theoretical maximum, based on glucose and xylose in the WIS)

$\begin{array}{llllll}\text { Glucan } & 90 & 94 & 88 & 89 & 86 \\ \text { Xylan } & 76 & 80 & 96 & 91 & 83\end{array}$

Process sugar yield (\% of theoretical maximum, based on glucose and xylose in the raw material)

$\begin{array}{llllll}\text { Glucose } & 88 & 91 & 84 & 86 & 82 \\ \text { Xylose } & 90 & 81 & 86 & 82 & 83\end{array}$

Sugar concentrations $\left(\mathrm{g} \mathrm{L}^{-1}\right)$

\begin{tabular}{clllll} 
Glucose & 101 & 93 & 78 & 92 & 82 \\
Xylose & 58 & 46 & 45 & 44 & 45 \\
Total & 159 & 139 & 124 & 135 & 127 \\
\hline
\end{tabular}

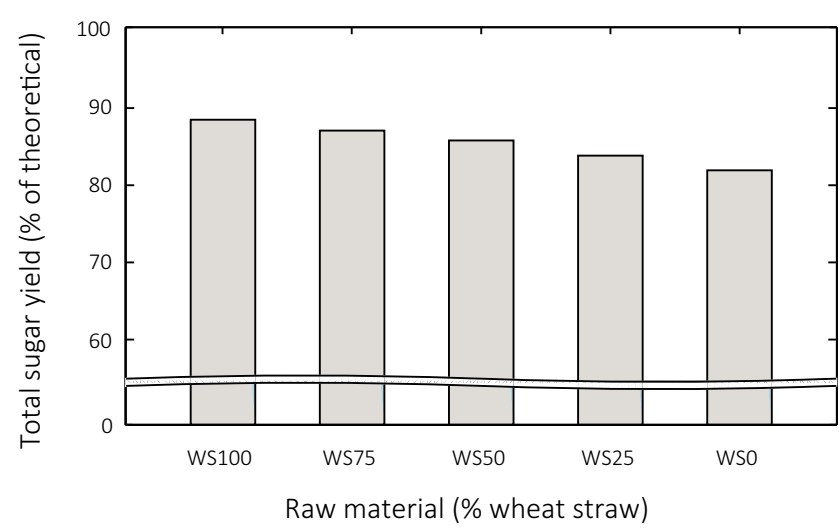

Fig. 4 Combined sugar yield after enzymatic hydrolysis. Combined process yield of glucose and xylose after enzymatic hydrolysis of dilute acid-catalysed steam pretreatment of wheat straw, corn stover, and various mixtures of the two, expressed as percentage of the theoretical maximum yield from the raw material

straw (WS100) were in the same range as previously reported for pretreatment conditions within the optimal range $[22,23]$. Meanwhile, the overall glucose yield for corn stover (WS0) was higher than the previously reported glucose yield at pretreatment conditions that maximised the total sugar yield after enzymatic hydrolysis [25]. Conversely, the obtained xylose yield was lower than previously reported [25], mainly due to increased xylose degradation during pretreatment. The enzymatic hydrolysis study confirmed that uniform pretreatment conditions can be used for wheat straw and corn stover, and likely for mixtures thereof. Sufficiently high total glucose and xylose concentrations were achieved (Table 3) to reach the desired ethanol concentrations and yields simultaneously.

\subsection{Simultaneous saccharification and cofermentation}

The conversion of pretreated feedstock mixtures to ethanol was performed with two different SSCF configurations: fed-batch SSCF with prefermentation of the hydrolysate liquor (Fig. 2a), referred to as fed-batch SSCF, and batch SSCF with prehydrolysis of the lignocellulosic solids (Fig. 2b), referred to as hybrid SSCF. The fed-batch $S S C F$ configuration has been employed previously for cofermentation of glucose and xylose derived from steam-pretreated wheat straw [40]. Technical ethanol yields exceeding $90 \%$ of the theoretical maximum and xylose utilisation exceeding $90 \%$ were achieved in that study. The hybrid SSCF configuration has previously been applied in attempts to improve enzymatic hydrolysis and ethanol yields in SSCF with various substrates [43, 44]. The performance of cofermentation and enzymatic hydrolysis in SSCF is summarised in Table 4. 
Table 4 Summary of the SSCF results. Hydrolysis and fermentation performance using the different SSCF configurations with various feedstock mixtures

\begin{tabular}{|c|c|c|c|c|c|c|c|c|c|c|}
\hline & \multicolumn{5}{|c|}{ Fed-batch SSCF } & \multicolumn{5}{|c|}{ Hybrid SSCF } \\
\hline & WS100 & WS75 & WS50 & WS25 & WS0 & WS100 & WS75 & WS50 & WS25 & WS0 \\
\hline \multicolumn{11}{|l|}{ Hydrolysis performance } \\
\hline Degree of glucan hydrolysis (\%) & 0.90 & 0.93 & 0.88 & 0.88 & 0.83 & 0.93 & 0.95 & 0.94 & 0.91 & 0.91 \\
\hline Degree of xylan hydrolysis (\%) & 0.69 & 0.84 & 0.69 & 0.76 & 0.71 & 0.77 & 0.85 & 0.80 & 0.83 & 0.77 \\
\hline \multicolumn{11}{|l|}{ Fermentation performance } \\
\hline Metabolic ethanol yield $\left(\mathrm{g} \mathrm{g}^{-1}\right)^{1}$ & 0.424 & 0.430 & 0.456 & 0.443 & 0.460 & 0.443 & 0.457 & 0.447 & 0.455 & 0.451 \\
\hline Glycerol production $\left(\mathrm{g} \mathrm{g}^{-1}\right)^{1}$ & 0.04 & 0.05 & 0.04 & 0.04 & 0.04 & 0.05 & 0.05 & 0.06 & 0.05 & 0.06 \\
\hline Xylitol production $\left(\mathrm{g} \mathrm{g}^{-1}\right)^{2}$ & 0.21 & 0.19 & 0.18 & 0.20 & 0.21 & 0.18 & 0.18 & 0.19 & 0.17 & 0.20 \\
\hline Xylose utilisation $(\%)^{3}$ & 92.5 & 89.2 & 91.6 & 86.1 & 88.8 & 97.9 & 94.8 & 97.0 & 95.2 & 96.6 \\
\hline Technical ethanol yield $\left(\mathrm{g} \mathrm{g}^{-1}\right)^{4}$ & 0.382 & 0.395 & 0.405 & 0.385 & 0.388 & 0.418 & 0.433 & 0.422 & 0.416 & 0.414 \\
\hline Process ethanol yield $\left(\mathrm{g} \mathrm{kg}^{-1}\right)^{5}$ & 195 & 194 & 199 & 187 & 190 & 213 & 213 & 207 & 202 & 202 \\
\hline \multicolumn{11}{|c|}{${ }^{1}$ Based on consumed glucose and xylose } \\
\hline \multicolumn{11}{|l|}{${ }^{2}$ Based on consumed xylose } \\
\hline \multicolumn{11}{|c|}{${ }^{3}$ Based on xylose liberated in pretreatment and enzymatic hydrolysis } \\
\hline \multicolumn{11}{|c|}{${ }^{4}$ Based on supplied glucose and xylose in the pretreated material } \\
\hline
\end{tabular}

\subsubsection{Fed-batch SSCF}

Prefermentation and fed-batch are modifications that are used in the fed-batch SSCF configuration which promote coconsumption of glucose and xylose by reducing the competitive uptake of glucose [41, 59, 60]. Prefermentation has been developed further into a method to enhance xylose uptake and conversion yield by converting it upfront under optimised conditions [40, 61]. Conversion of xylose, in addition to the hexose sugars glucose, galactose, and mannose, could theoretically increase the process ethanol yield from the single feedstocks and mixtures with 55-58\%. Process ethanol yield improvements with xylose fermentation exceeding $30 \%$ have been experimentally demonstrated with xylose-fermenting S. cerevisiae [45].

Fed-batch SSCF of all pretreated feedstocks and feedstock mixtures resulted in ethanol concentrations that exceeded the desired $50 \mathrm{~g} \mathrm{~L}^{-1}$ (Fig. 5). The higher ethanol concentration observed with WS100 reflected the higher recovery of glucose and xylose after pretreatment, compared with feedstock mixtures and corn stover. The lower ethanol concentration for WS50 was partly an effect of higher dilution in pretreatment than in the other mixtures (Table 2).

The metabolic ethanol yields obtained in fed-batch SSCF were in the range $0.42-0.46 \mathrm{~g} \mathrm{~g}^{-1}(83-90 \%$ of the theoretical maximum), with a tendency of increasing metabolic ethanol yield with increasing amounts of corn stover in the feedstock mixture. The glucose liberated by pretreatment and enzymatic hydrolysis was depleted during cofermentation. In contrast, residual fractions of xylose, representing $2-3 \%$ of the total xylose content in the pretreated material, were present in the fermentation broth at the end of SSCF. The xylose utilisation was $86-92 \%$ of the xylose liberated from the raw material by pretreatment and enzymatic hydrolysis.

The technical ethanol yields were in the range 0.38$0.41 \mathrm{~g} \mathrm{~g}^{-1}$ (75-79\% of theoretical maximum) with a uniform distribution across the range of feedstock mixtures. The higher technical ethanol yield of WS50 was attributed to the lower WIS content of the pretreated material, which affects enzymatic hydrolysis and cofermentation [62]. Limitations on the technical ethanol yields were the result of a low degree of glucan hydrolysis, incomplete utilisation of xylose, and byproduct formation during SSCF.

The discrepancy between the metabolic and technical ethanol yields reflects the enzymatic hydrolysis inefficiencies. The degree of hydrolysis of glucan and xylan after fed-batch SSCF was in the range $83-93 \%$ and $69-84 \%$, respectively, which was comparable to the hydrolysability evaluations (Table 3). Similar to the hydrolysability evaluations, the degree of glucan hydrolysis exhibited a decreasing trend with increasing ratio of corn stover in the mixture. The limited degree of xylan hydrolysis was of less importance for the technical ethanol yield, as most of the xylan was solubilised during pretreatment of all the feedstock mixtures (Fig. 3). In addition, considerable amounts of undesirable by-products were formed. On average, $0.20 \mathrm{~g} \mathrm{~g}^{-1}$ xylitol, based on consumed xylose, and $0.04 \mathrm{~g} \mathrm{~g}^{-1}$ glycerol, based on consumed glucose and xylose, were produced. By-product formation was similar across the range of feedstocks and feedstock mixtures. Typically between $0.05-0.1$ and $0.02-0.05 \mathrm{~g} \mathrm{~g}^{-1}$, based 


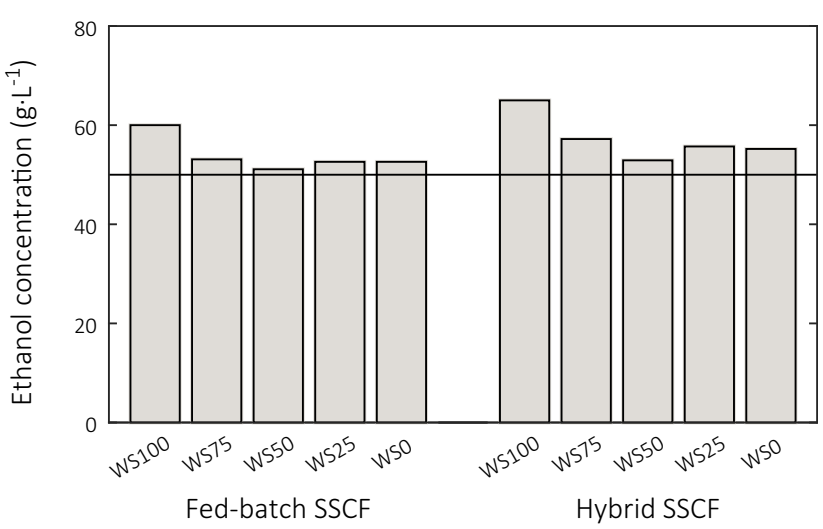

Fig. 5 Ethanol concentrations. Ethanol concentrations obtained in fedbatch SSCF and hybrid SSCF of dilute acid5-catalysed steam-pretreated wheat straw, corn stover, and various mixtures of the two. Vertical line represents the target concentration

on consumed glucose and xylose, of glycerol and biomass, respectively, is formed by xylose-fermenting $S$. cerevisiae during cofermentation of xylose and glucose in lignocellulosic hydrolysate [48, 63]. Further, typically $0.15-0.25 \mathrm{~g} \mathrm{~g}^{-1}$, based on consumed xylose, of xylitol is formed during fermentation of lignocellulosic hydrolysates by strains harbouring the xylose reductase and xylitol dehydrogenase pathway for xylose assimilation $[48,63]$. The similar technical ethanol yields obtained for all feedstock mixtures with fed-batch SSCF appeared to be the result of a trade-off between decreasing hydrolysability and increasing fermentability of the pretreated feedstock with increasing amounts of corn stover in the feedstock mixture.

\subsubsection{Hybrid SSCF}

Prehydrolysis of the whole slurry prior to SSCF was used in hybrid SSCF to resolve rheological issues [64] and alleviate the limitations on hydrolysis rate and, potentially, yield that are imposed by suboptimal temperatures in SSCF [44].

In hybrid SSCF, all pretreated feedstocks and feedstock mixtures showed ethanol concentrations that exceeded the target of $50 \mathrm{~g} \mathrm{~L}^{-1}$ (Fig. 5). Glucose and xylose liberated during hybrid SSCF were converted into ethanol resulting in metabolic yields in the range $0.44-0.46 \mathrm{~g} \mathrm{~g}^{-1}$ (87-90\% of the theoretical maximum), the variation being less than with fedbatch SSCF (Table 4). Glucose liberated by pretreatment and enzymatic hydrolysis was depleted, but low residual xylose concentrations were found at the end of cofermentation, representing less than $1.5 \%$ of the total sugar content. Xylose utilisation was $95-98 \%$ of the total liberated xylose.

The technical ethanol yields were in the range of $0.41-$ $0.43 \mathrm{~g} \mathrm{~g}^{-1}$ (81-85\% of the theoretical maximum), and consistent across the full range of feedstock mixtures (Fig. 6). The technical ethanol yields were mainly limited by incomplete glucan hydrolysis and by-product formation. The degrees of

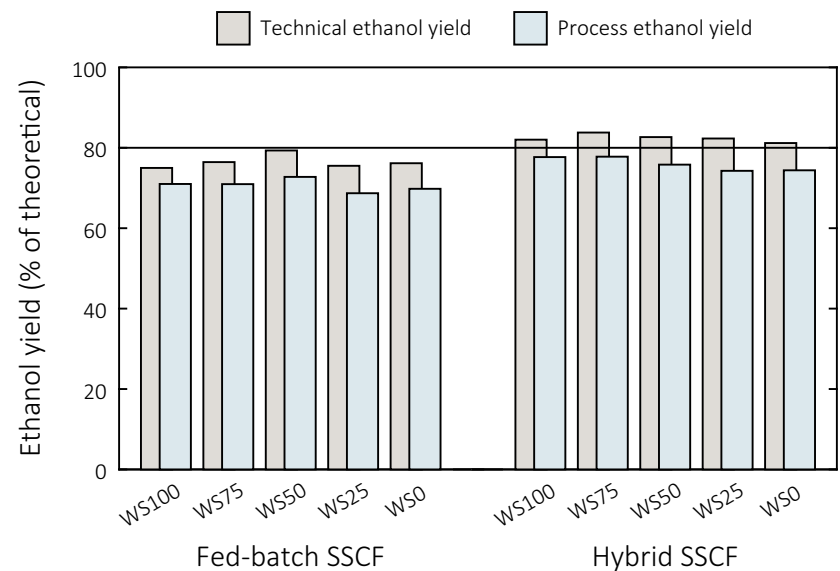

Fig. 6 Ethanol yields. Technical and process ethanol yields obtained with fed-batch SSCF and hybrid SSCF of dilute acid-catalysed steampretreated wheat straw, corn stover, and various mixtures of the two

hydrolysis of glucan and xylan after hybrid SSCF were in the range $91-95 \%$ and $77-85 \%$, respectively (Table 4), an improvement compared to the hydrolysability evaluations (Table 3) and fed-batch SSCF (Table 4). Similar to fed-batch $S S C F$, a decreasing trend in the degree of glucan hydrolysis was observed with an increasing ratio of corn stover in the mixture, leading to an increase in residual glucan after SSCF (Fig. 7). Furthermore, the ethanol yield was reduced by the formation of by-products. Xylitol and glycerol production was uniform at about $0.19 \mathrm{~g} \mathrm{~g}^{-1}$ of xylose and $0.06 \mathrm{~g} \mathrm{~g}^{-1}$ of total glucose and xylose, respectively. Although there were slight differences in xylitol and glycerol production compared to fed-batch SSCF, no significant differences were found in the number of carbons diverted to the major by-products between the two SSCF configurations.

Ethanol concentrations and ethanol yields were higher across the range of feedstock mixtures with hybrid SSCF compared to fed-batch SSCF (Figs. 5 and 6). The improvements were attributed to a combination of the improved efficiency of

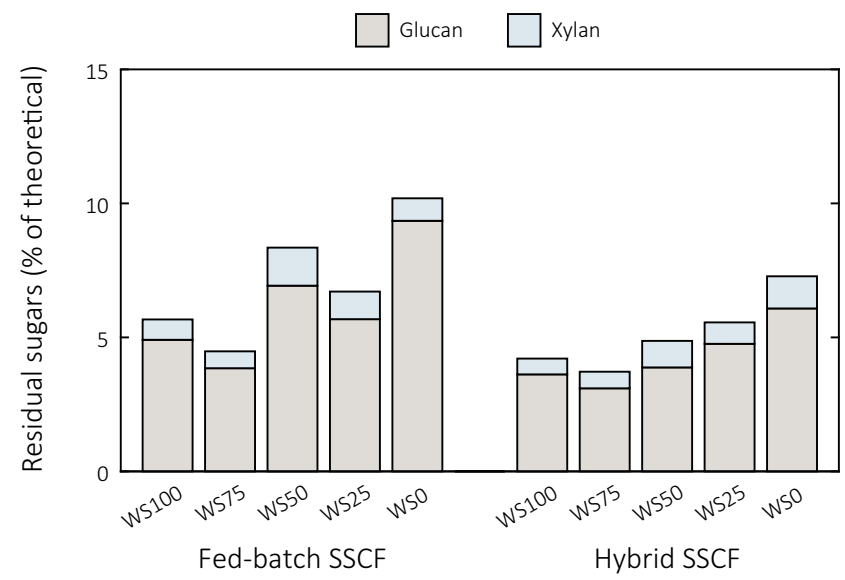

Fig. 7 Residual carbohydrates after SSCF. Residual glucan and xylan in the solid fraction after fed-batch SSCF and hybrid SSCF due to incomplete enzymatic hydrolysis (expressed as wt\% of total glucose and xylose in the pretreated materials) 
enzymatic hydrolysis and more consistent cofermentation performance. Whereas metabolic ethanol yields and by-product formation were similar across the range of feedstock mixtures in the two SSCF configurations, the degrees of glucan and xylan hydrolysis and xylose utilisation were better using the hybrid SSCF configuration (Table 4). The advantageous conditions for enzymatic hydrolysis, especially with regards to temperature, during the prehydrolysis step overcame possible limitations on hydrolysis due to the suboptimal temperatures used for enzymatic hydrolysis during SSCF. The degrees of glucan and xylan hydrolysis were more uniform across the range of feedstock mixtures, and were improved by $5 \%$ and $10 \%$, respectively, on average compared to fed-batch SSCF (Table 4), resulting in lower residual glucan and xylan contents in the solid residues after SSCF (Fig. 7). The other major contributor to the increased technical ethanol yield was the improved utilisation of liberated xylose (Table 4), which was improved by $7.5 \%$, on average.

\subsection{Integration of process steps and process analysis}

The interconnected process steps involved in the decomposition and conversion of lignocellulose to ethanol demands an analysis of the complete process from pretreatment to product in order to achieve industrially relevant ethanol concentrations and yields. Evaluation of the individual steps in the conversion process showed that the efficiency of pretreatment and the two different SSCF configurations was similar for wheat straw, corn stover, and various mixtures of the two. The combined yield of glucose and xylose obtained after pretreatment and enzymatic hydrolysis in this study was in agreement with previously reported maximum sugar yields from dilute acidcatalysed steam-pretreated wheat straw and corn stover [22, $23,25]$, which suggests that the application of identical pretreatment conditions was compatible with wheat straw and corn stover, separately and when mixed together. In addition, comparable technical ethanol yields were obtained across the full range of mixtures with both SSCF configurations (Fig. 6), although higher yields were observed with the hybrid SSCF compared to the fed-batch SSCF configuration.

Dilute acid-catalysed steam pretreatment reduced the potential process ethanol yield from the raw material both directly, by degrading sugars, and indirectly, due to the effects of the properties of the pretreated feedstock on enzymatic hydrolysis and cofermentation. Decreasing sugar recovery after pretreatment (Fig. 3) and decreasing glucan conversion in SSCF (Fig. 7) with increasing ratios of corn stover in the mixtures reduced the process ethanol yields systematically in both SSCF configurations (Fig. 6). The process ethanol yields in fed-batch and hybrid SSCF were in the range $187-195 \mathrm{~g} \mathrm{~kg}^{-1}$ and $202-213 \mathrm{~g} \mathrm{~kg}^{-1}$ of feedstock DM (69-72\% and 74-78\% of the theoretical maximum), respectively, based on the total amount of glucose and xylose in the raw materials. The process ethanol yields in fed-batch SSCF were uniformly distributed (Fig. 6), since the effects of decreasing recovery and hydrolysability were offset by increased fermentability (Table 4). In contrast, the process ethanol yields in hybrid $S S C F$ exhibited a decreasing trend with increasing ratio of corn stover in the mixture (Fig. 6). The decreasing sugar recoveries after pretreatment were reflected in the process ethanol yield, as a result of the similar cofermentation and hydrolysis performance. Despite the detrimental effects on process ethanol yield caused by pretreatment, the variation in process ethanol yields was low across the whole range of feedstocks and feedstock mixtures with both configurations. This suggests that wheat straw and corn stover could be used interchangeably. However, taking the similar process ethanol yields into account, using wheat straw as a single feedstock was most favourable as it resulted in higher ethanol concentrations than the mixtures (Fig. 5), which reduces the energy demand in the product recovery step [65].

Despite the consistency in both technical and process ethanol yields with both SSCF configurations, the efficiency of the pretreatment had a significant effect on the choice of SSCF configuration in the ensuing process. Restrictions resulting from pretreatment, e.g. lower and variable degrees of glucan and xylan hydrolysis (Table 4), constrained the process ethanol yield with the fed-batch SSCF configuration (Fig. 6). In contrast, the hybrid SSCF configuration could compensate for the trade-offs made in the pretreatment conditions, improving the ethanol concentrations and yields with all feedstocks and mixtures, making hybrid SSCF the preferred configuration.

The pretreatment conditions employed may have reduced the cofermentation efficiency when using the fed-batch SSCF configuration. The limitations on hydrolysis, preventing higher process ethanol yields from being attained with fedbatch SSCF, could probably have been alleviated by higher severity in the pretreatment, as higher severity implies improved hydrolysability. However, it also reduces the recovery of sugars, and leads to higher inhibitor concentrations in the pretreated feedstock. Technical ethanol yields exceeding 90\% of the theoretical maximum have previously been achieved with more severely dilute acid-catalysed steam-pretreated wheat straw with the same SSCF configuration and fermenting microorganism [40]. Technical ethanol yields of this magnitude could more than offset the decrease in the recovery of sugars, and thus increase the process ethanol yields. The difference in xylitol production between the studies is remarkable. In the current study, $21 \%$ of the consumed xylose in fed-batch SSCF was diverted to xylitol production, whereas $4.4 \%$ was diverted in the previous study [40]. This represents a considerable loss of carbon, which ought to have been converted to ethanol, to a non-recoverable by-product. The lower xylitol production was attributed to the higher amount of HMF and furfural generated by carbohydrate degradation in the pretreatment. These compounds can act as 
external redox sinks to alleviate the cofactor imbalance in the xylose assimilating pathway [66], which is responsible for xylitol accumulation and secretion [67], thereby improving xylose conversion. Further, they can inhibit growth and, thus, limit microbial biomass formation [68]. These mechanisms prevent excessive by-product production at the expense of compromised sugar recovery in the pretreatment and potential inhibition of the fermenting microorganism. This suggests that the pretreatment conditions that maximise the efficiency of cofermentation and the process ethanol yield might be different from those that maximise the recovery of fermentable sugars after pretreatment and enzymatic hydrolysis. This highlights the importance of clearly defining pretreatment goals when optimising the overall conversion process.

\section{Conclusions}

Ethanol concentrations exceeding $50 \mathrm{~g} \mathrm{~L}^{-1}$ and process ethanol yields in the range of $74-78 \%$ of the theoretical maximum were achieved over a range of identically pretreated feedstocks and feedstock mixtures of wheat straw and corn stover. Despite not reaching the targeted process ethanol yields ( $>80 \%$ of theoretical maximum), valuable insights were gained. The highest ethanol yields were obtained with hybrid SSCF, indicating that promotion of enzymatic hydrolysis efficiency in the bioconversion step is the key to compensating for compromises made in the pretreatment and attaining high ethanol yields. The narrow range of process ethanol yields obtained with the different feedstock mixtures suggests that wheat straw and corn stover can be used together at various ratios with conversion performance maintained, thus enabling hedging of economic, technological, and supply chain risks.

Acknowledgements Dr. Vera Novy, Department of Chemical Engineering, Lund University, is gratefully acknowledged for her valuable comments and critical review of the manuscript.

Availability of data and material The datasets supporting the conclusions of this article are included within the article.

Authors' contributions FN participated in the conception and design of the study, performed the experiments, and wrote the manuscript. OW and MG participated in the conception of the study and assisted in interpreting the data, participated in the editing and preparation of the final manuscript, and critically reviewed the manuscript. GZ assisted in interpreting the data, participated in the editing and preparation of the final manuscript, and critically reviewed the manuscript. All authors read and approved the final manuscript.

Funding The study was performed as part of the project, Process design for production of ethanol from mixed raw materials, funded by The Swedish Energy Agency (Grant number 38777-1).

\section{Compliance with ethical standards}

\section{Ethics approval and consent to participate Not applicable.}

Consent for publication Not applicable.

Conflict of interest The authors declare that they have no conflict of interest.

Abbreviations DM, dry matter; FPU, filter paper unit; HMF, 5hydroxymethylfurfural; HPLC, high-performance liquid chromatography; SSCF, simultaneous saccharification and cofermentation; vvm, gas volume flow per unit of liquid volume per minute; WIS, water-insoluble solids

Open Access This article is distributed under the terms of the Creative Commons Attribution 4.0 International License (http:// creativecommons.org/licenses/by/4.0/), which permits unrestricted use, distribution, and reproduction in any medium, provided you give appropriate credit to the original author(s) and the source, provide a link to the Creative Commons license, and indicate if changes were made.

\section{References}

1. Humbird D, Davis R, Tao L, Kinchin C, Hsu D, Aden A, Schoen P, Lukas J, Olthof B, Worley M, Sexton D, Dudgeon D (2011) Process design and economics for biochemical conversion of lignocellulosic biomass to ethanol: dilute-acid pretreatment and enzymatic hydrolysis of corn stover. Technical Report, NREL/TP-5100-47764. National Renewable Energy Laboratory, Golden, CO

2. Richard TL (2010) Challenges in scaling up biofuels infrastructure. Science 329(5993):793-796. https://doi.org/10.1126/science. 1189139

3. Jensen JW, Magid J, Hansen-Møller J, Andersen SB, Bruun S (2011) Genetic variation in degradability of wheat straw and potential for improvement through plant breeding. Biomass Bioenergy 35(3):1114-1120. https://doi.org/10.1016/j.biombioe.2010.11.036

4. Li X, Mupondwa E, Panigrahi S, Tabil L, Sokhansanj S, Stumborg M (2012) A review of agricultural crop residue supply in Canada for cellulosic ethanol production. Renew Sust Energ Rev 16(5): 2954-2965. https://doi.org/10.1016/j.rser.2012.02.013

5. Emerson R, Hoover A, Ray A, Lacey J, Cortez M, Payne C, Karlen D, Birrell S, Laird D, Kallenbach R, Egenolf J, Sousek M, Voigt T (2014) Drought effects on composition and yield for corn stover, mixed grasses, and Miscanthus as bioenergy feedstocks. Biofuels 5(3):275-291. https://doi.org/10.1080/17597269.2014.913904

6. Hess JR, Wright CT, Kenney KL (2007) Cellulosic biomass feedstocks and logistics for ethanol production. Biofuels Bioprod Biorefin 1(3):181-190. https://doi.org/10.1002/bbb.26

7. Golecha R, Gan J (2016) Cellulosic biorefinery portfolio and diversification: strategies to mitigate cellulosic biorefinery risks in US Corn Belt. Energy Strateg Rev 13:147-153. https://doi.org/10. 1016/j.esr.2016.09.003Get

8. Kenney KL, Smith WA, Gresham GL, Westover TL (2013) Understanding biomass feedstock variability. Biofuels 4(1):111127. https://doi.org/10.4155/bfs. 12.83

9. Vera RM, Bura R, Gustafson R (2015) Synergistic effects of mixing hybrid poplar and wheat straw biomass for bioconversion processes. Biotechnol Biofuels 8:226. https://doi.org/10.1186/s13068-0150414-9

10. Galbe M, Zacchi G (2002) A review of the production of ethanol from softwood. Appl Microbiol Biotechnol 59(6):618-628 
11. Merino S, Cherry J (2007) Progress and challenges in enzyme development for biomass utilization. Adv Biochem Eng Biotechnol 108:95-120. https://doi.org/10.1007/10 2007_066

12. Moutta RDO, Ferreira-Leitão VS, Bon EPDS (2014) Enzymatic hydrolysis of sugarcane bagasse and straw mixtures pretreated with diluted acid. Biocatal Biotransfor 32(1):93-100. https://doi.org/10. 3109/10242422.2013.873795

13. Pereira SC, Maehara L, Machado CMM, Farinas CS (2015) 2G ethanol from the whole sugarcane lignocellulosic biomass. Biotechnol Biofuels 8(1):44. https://doi.org/10.1186/s13068-0150224-0

14. Brodeur-Campbell M, Klinger J, Shonnard D (2012) Feedstock mixture effects on sugar monomer recovery following dilute acid pretreatment and enzymatic hydrolysis. Bioresour Technol 116: 320-326. https://doi.org/10.1016/j.biortech.2012.03.090

15. Shi J, Thompson VS, Yancey NA, Stavila V, Simmons BA, Singh S (2013) Impact of mixed feedstocks and feedstock densification on ionic liquid pretreatment efficiency. Biofuels 4(1):63-72. https:// doi.org/10.4155/bfs. 12.82

16. Shi J, George KW, Sun N, He W, Li C, Stavila V, Keasling JD, Simmons BA, Lee TS, Singh S (2015) Impact of pretreatment technologies on saccharification and isopentenol fermentation of mixed lignocellulosic feedstocks. Bioenergy Res 8(3):1004-1013. https:// doi.org/10.1007/s12155-015-9588-Z

17. Zhang H, Lopez PC, Holland C, Lunde A, Ambye-Jensen M, Felby C, Thomsen ST (2018) The multi-feedstock biorefinery-assessing the compatibility of alternative feedstocks in a $2 \mathrm{G}$ wheat straw biorefinery process. GCB Bioenergy 10(12):946-959. https://doi. org/10.1111/gcbb. 12557

18. Mosier N, Wyman C, Dale B, Elander R, Lee YY, Holtzapple M, Ladisch M (2005) Features of promising technologies for pretreatment of lignocellulosic biomass. Bioresour Technol 96(6):673-686. https://doi.org/10.1016/j.biortech.2004.06.025

19. Brethauer S, Studer MH (2015) Biochemical conversion processes of lignocellulosic biomass to fuels and chemicals - a review. CHIMIA Int J Chem 69(10):572-581. https://doi.org/10.2533/ chimia.2015.572

20. Ramos LP (2003) The chemistry involved in the steam treatment of lignocellulosic materials. Química Nova 26(6):863-871. https:// doi.org/10.1590/S0100-40422003000600015

21. Buranov AU, Mazza G (2008) Lignin in straw of herbaceous crops. Ind Crop Prod 28(3):237-259. https://doi.org/10.1016/j.indcrop. 2008.03.008

22. Linde M, Jakobsson E-L, Galbe M, Zacchi G (2008) Steam pretreatment of dilute $\mathrm{H}_{2} \mathrm{SO}_{4}$-impregnated wheat straw and SSF with low yeast and enzyme loadings for bioethanol production. Biomass Bioenergy 32(4):326-332. https://doi.org/10.1016/j.biombioe. 2007.09.013

23. Ballesteros I, Negro MJ, Oliva JM, Cabañas A, Manzanares P, Ballesteros M (2006) Ethanol production from steam-explosion pretreated wheat straw. Appl Biochem Biotechnol 130(1):496508. https://doi.org/10.1007/978-1-59745-268-7 41

24. Zimbardi F, Viola E, Nanna F, Larocca E, Cardinale M, Barisano D (2007) Acid impregnation and steam explosion of corn stover in batch processes. Ind Crop Prod 26(2):195-206. https://doi.org/10. 1016/j.indcrop.2007.03.005

25. Bondesson P-M, Galbe M, Zacchi G (2013) Ethanol and biogas production after steam pretreatment of corn stover with or without the addition of sulphuric acid. Biotechnol Biofuels 6(1):1-11. https://doi.org/10.1186/1754-6834-6-11

26. Olofsson K, Bertilsson M, Lidén G (2008) A short review on SSF an interesting process option for ethanol production from lignocellulosic feedstocks. Biotechnol Biofuels 1:7. https://doi.org/10.1186/ 1754-6834-1-7

27. Torija MJ, Rozès N, Poblet M, Guillamón JM, Mas A (2003) Effects of fermentation temperature on the strain population of
Saccharomyces cerevisiae. Int J Food Microbiol 80(1):47-53. https://doi.org/10.1016/S0168-1605(02)00144-7

28. Jeffries TW, Jin Y-S (2000) Ethanol and thermotolerance in the bioconversion of xylose by yeasts. Adv Appl Microbiol 47:221268. https://doi.org/10.1016/S0065-2164(00)47006-1

29. Singhania RR, Sukumaran RK, Patel AK, Larroche C, Pandey A (2010) Advancement and comparative profiles in the production technologies using solid-state and submerged fermentation for microbial cellulases. Enzym Microb Technol 46(7):541-549. https:// doi.org/10.1016/j.enzmictec.2010.03.010

30. Aldiguier AS, Alfenore S, Cameleyre X, Goma G, Uribelarrea JL, Guillouet SE, Molina-Jouve C (2004) Synergistic temperature and ethanol effect on Saccharomyces cerevisiae dynamic behaviour in ethanol bio-fuel production. Bioprocess Biosyst Eng 26(4):217222. https://doi.org/10.1007/s00449-004-0352-6

31. Ramos MT, Madeira-Lopes A (1990) Effects of acetic acid on the temperature profile of ethanol tolerance in Saccharomyces cerevisiae. Biotechnol Lett 12(3):229-234. https://doi.org/10. 1007/BF01026805

32. Lu Y, Cheng Y-F, He X-P, Guo X-N, Zhang B-R (2012) Improvement of robustness and ethanol production of ethanologenic Saccharomyces cerevisiae under co-stress of heat and inhibitors. J Ind Microbiol Biotechnol 39(1):73-80. https:// doi.org/10.1007/s10295-011-1001-0

33. Mutturi S, Liden G (2013) Effect of temperature on simultaneous saccharification and fermentation of pretreated spruce and arundo. Ind Eng Chem Res 52(3):1244-1251. https://doi.org/10.1021/ ie302851w

34. Tengborg C, Galbe M, Zacchi G (2001) Reduced inhibition of enzymatic hydrolysis of steam-pretreated softwood. Enzym Microb Technol 28(9):835-844. https://doi.org/10.1016/S01410229(01)00342-8

35. Meinander NQ, Hahn-Hagerdal B (1997) Influence of cosubstrate concentration on xylose conversion by recombinant, XYL1expressing Saccharomyces cerevisiae: a comparison of different sugars and ethanol as cosubstrates. Appl Environ Microbiol 63(5): 1959-1964

36. Meinander NQ, Boels I, Hahn-Hägerdal B (1999) Fermentation of xylose/glucose mixtures by metabolically engineered Saccharomyces cerevisiae strains expressing XYL1 and XYL2 from Pichia stipitis with and without overexpression of TAL1. Bioresour Technol 68(1):79-87. https://doi.org/10.1016/S09608524(98)00085-6

37. Olofsson K, Rudolf A, Lidén G (2008) Designing simultaneous saccharification and fermentation for improved xylose conversion by a recombinant strain of Saccharomyces cerevisiae. J Biotechnol 134(1-2):112-120. https://doi.org/10.1016/j.jbiotec.2008.01.004

38. Subtil T, Boles E (2012) Competition between pentoses and glucose during uptake and catabolism in recombinant Saccharomyces cerevisiae. Biotechnol Biofuels 5:14. https://doi.org/10.1186/ 1754-6834-5-14

39. Kim J-H, Block DE, Mills DA (2010) Simultaneous consumption of pentose and hexose sugars: an optimal microbial phenotype for efficient fermentation of lignocellulosic biomass. Appl Microbiol Biotechnol 88(5):1077-1085. https://doi.org/10.1007/s00253-0102839-1

40. Nielsen F, Zacchi G, Galbe M, Wallberg O (2017) Sequential targeting of xylose and glucose conversion in fed-batch simultaneous saccharification and cofermentation of steam-pretreated wheat straw for improved xylose conversion to ethanol. Bioenerg Res 10(3):800-810. https://doi.org/10.1007/s12155-017-9841-8

41. Bertilsson M, Olofsson K, Lidén G (2009) Prefermentation improves xylose utilization in simultaneous saccharification and cofermentation of pretreated spruce. Biotechnol Biofuels 2:8. https:// doi.org/10.1186/1754-6834-2-8 
42. Olofsson K, Palmqvist B, Lidén G (2010) Improving simultaneous saccharification and co-fermentation of pretreated wheat straw using both enzyme and substrate feeding. Biotechnol Biofuels 3: 17. https://doi.org/10.1186/1754-6834-3-17

43. Öhgren K, Vehmaanperä J, Siika-Aho M, Galbe M, Viikari L, Zacchi G (2007) High temperature enzymatic prehydrolysis prior to simultaneous saccharification and fermentation of steam pretreated corn stover for ethanol production. Enzym Microb Technol 40(4):607-613. https://doi.org/10.1016/j.enzmictec.2006. 05.014

44. Palmqvist B, Lidén G (2014) Combining the effects of process design and $\mathrm{pH}$ for improved xylose conversion in high solid ethanol production from Arundo donax. AMB Express 4(1):41. https://doi. org/10.1186/s13568-014-0041-z

45. Novy V, Longus K, Nidetzky B (2015) From wheat straw to bioethanol: integrative analysis of a separate hydrolysis and cofermentation process with implemented enzyme production. Biotechnol Biofuels 8(1):1-12. https://doi.org/10.1186/s13068015-0232-0

46. Bondesson P-M, Galbe M, Zacchi G (2014) Comparison of energy potentials from combined ethanol and methane production using steam-pretreated corn stover impregnated with acetic acid. Biomass Bioenergy 67:413-424. https://doi.org/10.1016/j. biombioe.2014.05.025

47. Tomás-Pejó E, Bonander N, Olsson L (2014) Industrial yeasts strains for biorefinery solutions: constructing and selecting efficient barcoded xylose fermenting strains for ethanol. Biofuels Bioprod Biorefin 8(5):626-634. https://doi.org/10.1002/bbb.1472

48. Novy V, Wang R, Westman JO, Franzén CJ, Nidetzky B (2017) Saccharomyces cerevisiae strain comparison in glucose-xylose fermentations on defined substrates and in high-gravity SSCF: convergence in strain performance despite differences in genetic and evolutionary engineering history. Biotechnol Biofuels 10:205. https://doi.org/10.1186/s13068-017-0887-9

49. Wahlbom CF, van Zyl WH, Jönsson LJ, Hahn-Hägerdal B, Otero RRC (2003) Generation of the improved recombinant xyloseutilizing Saccharomyces cerevisiae TMB 3400 by random mutagenesis and physiological comparison with Pichia stipitis CBS 6054. FEMS Yeast Res 3(3):319-326. https://doi.org/10.1016/ S1567-1356(02)00206-4

50. Taherzadeh MJ, Lidén G, Gustafsson L, Niklasson C (1996) The effects of pantothenate deficiency and acetate addition on anaerobic batch fermentation of glucose by Saccharomyces cerevisiae. Appl Microbiol Biotechnol 46(2):176-182. https://doi.org/10.1007/ s002530050801

51. Nielsen F, Tomás-Pejó E, Olsson L, Wallberg O (2015) Short-term adaptation during propagation improves the performance of xylosefermenting Saccharomyces cerevisiae in simultaneous saccharification and co-fermentation. Biotechnol Biofuels 8(1):1-15. https:// doi.org/10.1186/s13068-015-0399-4

52. Sluiter A, Hames B, Ruiz R, Scarlata C, Sluiter J, Templeton D (2008) Determination of sugars, byproducts, and degradation products in liquid fraction process samples. Laboratory Analytical Procedure, NREL/TP-510-42623. National Renewable Energy Laboratory, Golden, $\mathrm{CO}$

53. Sluiter A, Hames B, Ruiz R, Scarlata C, Sluiter J, Templeton D, Crocker D (2012) Determination of structural carbohydrates and lignin in biomass. Laboratory Analytical Procedure, NREL/TP510-42618. National Renewable Energy Laboratory, Golden, CO.

54. Kristensen JB, Felby C, Jørgensen H (2009) Determining yields in high solids enzymatic hydrolysis of biomass. Appl Biochem Biotechnol 156(1):127-132. https://doi.org/10.1007/s12010-0088375-0
55. Zhu Y, Malten M, Torry-Smith M, McMillan JD, Stickel JJ (2011) Calculating sugar yields in high solids hydrolysis of biomass. Bioresour Technol 102(3):2897-2903. https://doi.org/10.1016/j. biortech.2010.10.134

56. Grohmann K (1993) Simultaneous saccharification and fermentation of cellulosic substrates to ethanol. In: Saddler JN (ed) Bioconversion of forest and agricultural plant residues. $\mathrm{CAB}$ International, Wallingford, pp 183-183

57. Lloyd TA, Wyman CE (2005) Combined sugar yields for dilute sulfuric acid pretreatment of corn stover followed by enzymatic hydrolysis of the remaining solids. Bioresour Technol 96(18): 1967-1977. https://doi.org/10.1016/j.biortech.2005.01.011

58. Palmqvist E, Hahn-Hägerdal B (2000) Fermentation of lignocellulosic hydrolysates. II: inhibitors and mechanisms of inhibition. Bioresour Technol 74(1):25-33. https://doi.org/10.1016/S09608524(99)00161-3

59. Jin M, Lau MW, Balan V, Dale BE (2010) Two-step SSCF to convert AFEX-treated switchgrass to ethanol using commercial enzymes and Saccharomyces cerevisiae 424A(LNH-ST). Bioresour Technol 101(21):8171-8178. https://doi.org/10.1016/j. biortech.2010.06.026

60. Koppram R, Nielsen F, Albers E, Lambert A, Wännström S, Welin L, Zacchi G, Olsson L (2013) Simultaneous saccharification and co-fermentation for bioethanol production using corncobs at lab, PDU and demo scales. Biotechnol Biofuels 6:2. https://doi.org/10. 1186/1754-6834-6-2

61. Nielsen F, Zacchi G, Galbe M, Wallberg O (2016) Prefermentation improves ethanol yield in separate hydrolysis and cofermentation of steam-pretreated wheat straw. Sustain Chem Process 4:10. https:// doi.org/10.1186/s40508-016-0054-9

62. Lu Y, Wang Y, Xu G, Chu J, Zhuang Y, Zhang S (2010) Influence of high solid concentration on enzymatic hydrolysis and fermentation of steam-exploded corn stover biomass. Appl Biochem Biotechnol 160(2):360-369. https://doi.org/10.1007/s12010-008-8306-0

63. Novy V, Krahulec S, Wegleiter M, Müller G, Longus K, Klimacek M, Nidetzky B (2014) Process intensification through microbial strain evolution: mixed glucose-xylose fermentation in wheat straw hydrolyzates by three generations of recombinant Saccharomyces cerevisiae. Biotechnol Biofuels 7(1):49. https://doi.org/10.1186/ 1754-6834-7-49

64. Jørgensen H, Vibe-Pedersen J, Larsen J, Felby C (2007) Liquefaction of lignocellulose at high-solids concentrations. Biotechnol Bioeng 96(5):862-870. https://doi.org/10.1002/bit. 21115

65. Galbe M, Sassner P, Wingren A, Zacchi G (2007) Process engineering economics of bioethanol production. Adv Biochem Eng Biotechnol 108. doi https://doi.org/10.1007/10_2007_063

66. Wahlbom CF, Hahn-Hägerdal B (2002) Furfural, 5-hydroxymethyl furfural, and acetoin act as external electron acceptors during anaerobic fermentation of xylose in recombinant Saccharomyces cerevisiae. Biotechnol Bioeng 78(2):172-178. https://doi.org/10. 1002/bit.10188

67. Kötter P, Ciriacy M (1993) Xylose fermentation by Saccharomyces cerevisiae. Appl Microbiol Biotechnol 38(6):776-783. https://doi. org/10.1007/BF00167144

68. Almeida JM, Bertilsson M, Gorwa-Grauslund M, Gorsich S, Lidén G (2009) Metabolic effects of furaldehydes and impacts on biotechnological processes. Appl Microbiol Biotechnol 82(4):625-638. https://doi.org/10.1007/s00253-009-1875-1

Publisher's note Springer Nature remains neutral with regard to jurisdictional claims in published maps and institutional affiliations. 